ct-Dec 2018

C.

\title{
Palm species richness, latitudinal gradients, sampling effort, and deforestation in the Amazon region
}

\section{Carlos Mariano Alvez-Valles ${ }^{1,5 *}$ (D) Henrik Balslev ${ }^{2}$, Roosevelt Garcia-Villacorta ${ }^{3,4}$ (D) Fabrício Alvim Carvalho ${ }^{5}$ and Luiz Menini Neto ${ }^{5}$}

Received: November 20, 2017

Accepted: February 19, 2018

\begin{abstract}
Palms are most diverse in warm and humid regions near the equator. Though palms remain relatively well conserved, they are under increasing pressure from deforestation. Here, we analyze patterns of palm species richness relative to latitudinal gradient, sampling effort, and deforestation in the Amazon, and compare patterns of richness and floristic similarity among Amazonian sub-regions. We built a database of 17,310 records for 177 species. The areas with the greatest richness were in the western, central and northeastern Amazon, principally at latitudes $0-5^{\circ} \mathrm{S}$. Species richness and the number of records were highly correlated $\left(\mathrm{R}^{2}=0.76, \mathrm{P}<0.005\right)$. The highest rates of deforestation $\left(\geq 2000 \mathrm{~km}^{2}\right)$ were found in the southern and eastern Amazon of Brazil, which coincide with low richness and gaps in records. Similarity analyzes resulted in two groups of sub-regions: the first included the Amazon s.s., the Andes and the Guiana, while the second included the Plateau and Gurupi. We conclude that the highest species richness is at low latitudes, and observed richness is affected by sampling effort and is vulnerable to deforestation. Therefore, areas with low species richness, especially areas with data deficiency, need to be further studied for a better understanding of their patterns of diversity and richness.
\end{abstract}

Keywords: Amazon palms, Amazon sub-regions, ecology of palms, richness patterns, species occurrence records

\section{Introduction}

Understanding the spatial distribution of biodiversity is fundamental for its use, management and conservation (Mutke \& Barthlott 2005). The Amazon presents high plant species richness not only at the regional scale (Steege et al. 2015), but also at very local scales (Gentry 1988; Balslev et al. 1998; 2011; Oliveira \& Mori 1999; Steege et al. 2000). Moreover, the richness varies along latitudinal gradients (Barthlott et al. 2005; 2007), and floristic variability evolved also under the influence of climatic, soil and ecological drivers (Gentry 1988; Pitman et al. 2001; Vormisto 2002; Steege et al. 2003; Haugaasen \& Peres 2006; Honorio et al. 2008). Although the Amazon is still relatively wellconserved, it is subject to deforestation with profound regional and global implications (WWF 2014), and uneven data records from the region makes it difficult to study.

Plant diversity is very unevenly distributed across the globe (Barthlott et al. 2005). In general, plant diversity increases toward the equator (Barthlott et al. 2005; 2007) but not all tropical regions are necessarily richer in plant species than subtropical or temperate ones (Barthlott et al. 2007). The biodiversity of a particular area depends not

1 Programa de Pós-Graduação em Ecologia, Instituto de Ciências Biológicas, Universidade Federal de Juiz de Fora, 36036-900, Juiz de Fora, MG, Brazil

2 Section for Ecoinformatics and Biodiversity, Department of Bioscience, Aarhus University, Ny Munkegade 114, DK-8000 Aarhus C., Denmark 3 Department of Ecology and Evolutionary Biology, Corson Hall, Cornell University, 215 Tower Road, 14850, Ithaca, New York, USA

4 Peruvian Center for Biodiversity and Conservation, Nanay 373, Iquitos, Peru

5 Departamento de Botânica, Instituto de Ciências Biológicas, Universidade Federal de Juiz de Fora, 36036-900, Juiz de Fora, MG, Brazil

* Corresponding author: marianoalvez@gmail.com 
only on historical factors and its location, but also on the diversity of abiotic factors (e.g., soils, climate, altitudinal changes, and fire regimes) (Barthlott et al. 1996; 2005; Mutke \& Barthlott 2005). Thus, several geographical studies on species distributions and diversity (e.g., Steege et al. 2000; 2003; 2006; Pitman et al. 2001; 2002; Bjorholm et al. 2005; 2006; Heijden \& Phillips 2009; Blach-Overgaard et al. 2010; Eiserhardt et al. 2011b; Vedel-Sørensen et al 2013) provide insights into the roles played by climate, topography, biotic interactions, and dispersal limitations in shaping the Amazon's diversity (Pearson \& Dawson 2003; Gaston 2009). In fact, most of the global centers of plant diversity (those with $>5,000$ species per 10,000 $\mathrm{km}^{2}$ ) are located in mountainous regions of humid tropics (Costa Rica to the Chocó, Tropical eastern Andes, Atlantic Brazil, northern Borneo, New Guinea), where suitable climatic conditions and high levels of geodiversity coincide (Barthlott et al. 2005; 2007). The patterns of plant richness related to climate (mean annual temperature, annual water deficit, and their interaction) are globally consistent and are independent of the diverse evolutionary histories and functional assemblages of plants in different part of the world (Francis \& Currie 2003). In high energy regions, like the tropics and subtropics, the influence of water availability gains a stronger influence resulting in higher correlations coefficients with factors, like actual evapotranspiration, annual precipitation, or the number of dry months (Barthlott et al. 2005).

The Amazon region maintains a dynamic and suitable environmental heterogeneity for palms (Arecaceae) diversification. The Amazon has fewer threatened palm species than other Neotropical biogeographical regions such as the Caribbean, the Pacific coast, and the Andes (Balslev et al. 2015). There are some evident biogeographical patterns for palms in the Amazon region, whose diversity follows a gradient of rainfall with the humid areas being much richer, except for genera as Attalea sensu stricto and Syagrus which both show opposite tendencies (Pintaud et al. 2008). The western Amazon is distinguished by endemism at the generic level (e.g., Aphandra, Itaya, Wendlandiella) and especially by a high level of species endemism (Alvez-Valles et al. 2018). The central Amazon region also has its own endemisms, but at the species level (e.g., Astrocaryum ferrugineum, A. sociale, Bactris balanophora, B. tefensis, Geonoma aspidiifolia, G. oligoclona, Iriartella setigera, Oenocarpus minor). This may relate to local geological features and a dry corridor barrier to the north, and possibly to the presence of refuges during the Pleistocene (Prance 1973). Other parts of the Amazon region are comparatively less diverse, but stand out for their floristic composition. The diversity is highest in non-flooded forests (terra firme), while flooded forests are less diverse (Kahn \& Granville 1992). Palms occur in different habitat types (Balslev et al. 2015), the topography determines their distribution (Kahn \& Castro 1985; Vormisto et al. 2004b), and have great influence on the forest structure (Kahn \&
Mejia 1990). In addition, their taxonomy is relatively well known (Gentry 1991; Henderson et al. 1995), making this group suitable for meta-analyzes.

A commonly discussed pattern in palms and many other organisms is the variation in number of species per unit area, when latitude varies, which is referred to as the latitudinal gradient in which the number of species diminishes when moving away from the equator (Pianka 1966). Many explanations, both biotic and abiotic, have been proposed to explain the latitudinal gradient (Stiling 1996). Biotic explanations include the hypotheses of competition (Dobzhansky 1950), predation (Paine 1966) and zoophilia (Stiling 1996). Abiotic explanations include the hypotheses of climate stability (Klopfer 1959), ecological time (Fischer 1960), productivity (Connell \& Orias 1964) and area (Terborgh 1973). Some hypotheses include both biotic and abiotic factors such as spatial heterogeneity (Miller 1958; MacArthur \& MacArthur 1961) and ecological refuges (Haffer 1969; Vanzolini 1970; Brown \& Ab'Saber 1979). Most of these hypotheses have not been tested and some are not testable (Stiling 1996). All of them, however, were proposed based on the number of species of one or a few taxa (genera, families, order, class, etc.), but still the findings were often generalized as if they were valid for all taxa in the community even if it is well known that some taxa have opposite trends in their species richness, a fact that must be considered for a deeper understanding of the latitudinal gradient. A meta-analysis showed that species richness of most taxa increases towards the equator (Hillebrand 2004) and this trend is substantially stronger at regional compared to local scales (Mittelbach et al. 2007).

Deforestation in the Amazon region increased explosively with road constructions that allowed human expansion and irregular occupation of lands, and predatory exploration of noble woods (Fearnside 1992). Consequently, illegal wood exploration that increases fire susceptibility and selective logging that causes extensive damage to nearby trees and soils, increase the risk of species extinction and carbon emissions. Open roads that permits unplanned development, and exploration of forest that convert them into family agriculture and pasture are main causes of deforestation (Veríssimo et al. 1992; Johns et al. 1996; Holdsworth \& Uhl 1997; Souza Jr et al. 2003). Moreover, the primary adverse effect of tropical deforestation is massive extinction of species (Whitmore \& Sayer 1992; Turner 1996) and impacts on local and global climate (Laurance et al. 2004). Therefore, deforestation is a major threat to biodiversity (Skole \& Tucker 1993; Turner 1996). In the last decades, the Amazon has experienced rapid land use change. An area of 763,000 $\mathrm{km}^{2}$ had been deforested up to 2013 in the Brazilian Amazon alone (Nobre 2014), suggesting that $47 \%$ of the Brazilian Amazon would be deforested by 2050 (Soares et al. 2006). Additionally, deforestation rates within other Amazon countries are increasing (Soares et al. 2014). Hansen et al. (2013) mention that the tropics 
are the only domain to show statistically significant trend in annual forest loss, with an estimated increase in loss at $2101 \mathrm{~km}^{2} /$ year. Tropical rainforest ecotones totaled $32 \%$ of global forest cover loss, nearly half of which occurred in South American rainforests (Hansen et al. 2013). In recent years, Brazil has substantially reduced deforestation rates (Hansen et al. 2013). However, large reductions in Amazon basin forest cover may still occur in the future (Spracklen \& Garcia-Carreras 2015). Thus, all projections for the future of the Amazon over the current century, predict large-scale deforestation in the region (Laurance et al. 2004). Some palm species are adapted to high levels of disturbance and seem to benefit from deforestation and forest fragmentation, adjusting their reproductive strategies to better use these high-luminosity conditions (Barot et al. 2005). However, most palm species are vulnerable to such anthropogenic changes (Salm et al. 2001).

Species richness is widely used in ecological studies. Beyond the particular nature of the community, the calculated species richness is strongly affected by sampling effort (Lande et al. 2000). That is, the greater the collection effort, the greater the species richness (Melo \& Hepp 2008). Furthermore, species richness should be considered directly related to the number of individuals, area and variety of habitats sampled (Schluter \& Ricklefs 1993). One of the most used forms of analysis is the construction of relationships between sample effort and number of species sampled. The analysis consists of figures relating the sample effort (number of individuals sampled or sample area) cumulative ( $\mathrm{X}$ axis) to the cumulative number of species sampled ( $\mathrm{Y}$ axis). This curve is logarithmic: as the sample area increases, at the beginning the number of species increases rapidly, then slowly and, finally very little (Pielou 1975; 1977).

Spatial scale has become increasingly important in ecology (Franklin 2009), using digital biodiversity databases, that permit assembly of species occurrence data from various sources, such as herbaria and museums, as well as data from the literature (Graham et al. 2004; Yesson et al. 2007). The current demand for reliable, easily accessible and free biodiversity data makes electronic infrastructures fundamental for facilitating access (Canhos et al. 2015). There are different international databases such as the Global Biodiversity Information Facility (GBIF), Species link, INCT - Herbário Virtual da Flora e dos Fungos, NeoTropTree, and others that strive to make the world's biodiversity data globally accessible via the internet and data sharing protocols (Franklin 2009). These databases are used in plant ecology for analysis of species distribution (Bjorholm et al. 2006; Salm et al. 2007; Werneck et al. 2011), areas of endemism (Sigrist \& Carvalho 2008; Werneck et al. 2011; Menini Neto et al. 2016; Alvez-Valles et al. 2018); effects of climate change on plants (Blach-Overgaard et al. 2010; Feeley \& Silman 2011; Patiño et al. 2016) and others.

Previous palm studies (Bjorholm et al. 2005; 2006; BlachOvergaard et al. 2010; Vedel-Sørensen et al. 2013) have analyzed distribution in the American and in the African continents. Here, we have assembled a large georeferenced database of locations for palm species in the Amazon region to answer the following questions: (1) How is palm species richness distributed spatially and latitudinally in the Amazon region? (2) Is the observed palm species richness related to sample effort? (3) Are low richness and record gaps related to deforestation? and (4) Are there floristic similarities in palms distribution patterns among the five Amazonian sub-regions?

\section{Materials and methods}

\section{Study area}

Our study area covers the entire Amazon watershed from its highest altitude spring areas in the surrounding mountain systems, to the river mouth in the extreme east $\left(8,121,313 \mathrm{~km}^{2}\right)$ (Eva \& Huber 2005). This area can be divided into the central Amazon (Amazon sensu stricto) (68\%) and four peripheral sub-regions: Guiana (12\%), Plateau (11\%), Andes (7\%), and Gurupi (2\%) (Fig. 1A). This delimitation, proposed by Eva \& Huber (2005), was based on hydrographic, ecological, and biogeographical criteria as follows.

The Amazon sub-region (sensu stricto) $\left(5,569,174 \mathrm{~km}^{2}\right)$ is defined by the boundary of the Amazon River Basin to the north, an outline of $700 \mathrm{~m}$ to the west and the Amazon forest (before exploration) to the south and southeast. Average annual temperature (AAT) is $>24^{\circ} \mathrm{C}$, and mean annual rainfall (MAR) is $>1400 \mathrm{~mm}$. Several tropical soil types with different chemical and physical properties are found in this sub-region. It harbors flooded or non-flooded terrain, including floodplains and so-called igapó, which is peculiar by being flooded by black waters. The region also includes coastal forest (mangroves) and marshes along the Atlantic Ocean.

The Andes sub-region $\left(555,564 \mathrm{~km}^{2}\right)$ stretches from 700 $m$ elevation to the sources of the Amazon River at the edge of the watershed along the top of the Andes. Therefore, the sub-region includes all submontane, mountainous, and high Andean (alpine) ecosystems, such as: humid montane forests, cloud forests, yungas, páramos, punas, jalcas, chirivitales, etc., with their corresponding faunistic associations that inhabit the eastern slopes of the Andean Cordillera, from Colombia in the north, through Ecuador and Peru to Bolivia in the south.

The Plateau sub-region $\left(864,951 \mathrm{~km}^{2}\right)$ is the area between the confines of the Amazon rainforest in the plains and the limits of the Amazonas/Tocantins watershed spring areas in Bolivia and Brazil. This sub-region contains a considerable portion of savanna (cerradão) and shrubby savanna (cerrado), characteristic of the landscape of the Brazilian central plateau. The lowlands of eastern Bolivia, consists of an extensive mosaic of evergreen forest, with 


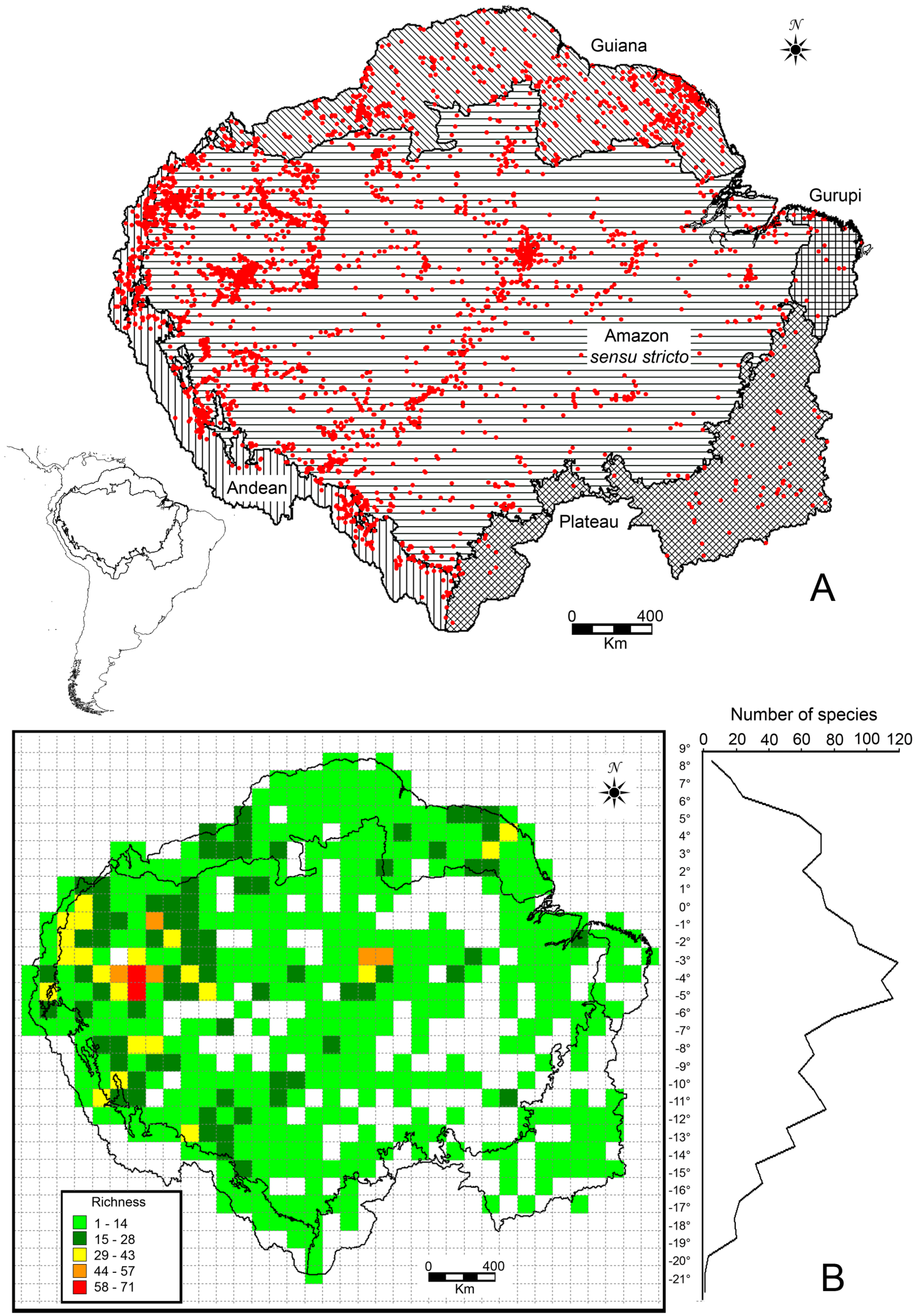

Figure 1. A. Distribution of 17.310 records of occurrence of 177 Amazonian palm species in the Amazon region (red dots). B. Left: Species richness of palms in the Amazon in grid squares of $1^{\circ} \times 1^{\circ}$. Right: Species richness distribution in latitude extents (in decimal degrees) for the distributional range of 177 Amazonian palms especies in the Amazon region. Area divided in a central sub-region Amazon sensu stricto, and four peripheral sub-regions - Andes, Guiana, Gurupi and Plateau. Source: Eva \& Huber (2005). Please see the PDF version for color reference. 
drier forest patches alternating with floodplain savannas and palm marshes, which in turn are bordered to the south by the dry forest of Chiquitania and the formation known as chaco.

The Guiana sub-region $\left(970,161 \mathrm{~km}^{2}\right)$ is bordered to the north by the Atlantic coast and by the Orinoco and Vichada rivers, while the southern boundary is formed by the watershed of the Amazon basin. The mountains of the Guiana massif are surrounded by extensive promontory (glacis) that result from the continuous accumulation of erosion products on the heights and slopes of the tepuis and their subsequent transport to the downstream hydrological network. Only the rivers of the southern and southwestern sections of the Guiana massif pour into the Amazon River; the northwest and north sections pour into the Orinoco River; in turn, the rivers originating in the three Guianas flow directly into the northern coast of the Atlantic Ocean.

The Gurupi sub-region $\left(161,463 \mathrm{~km}^{2}\right)$ is located to the east, outside the limits of the Amazonas/Tocantins watersheds, but it is included in the Amazon forest. This sub-region includes the basins of the following rivers that flow directly to the Marajó bay or the Atlantic Ocean, to the east of Tocantins: Mojú/Acará, Capim, Gurupi, Turiaçú and Pindaré; Pindaré River, towards the sources of the Mearim and, until reaching the division with the Tocantins in Serra do Gado Bravo in the state of Maranhão (Brazil).

\section{Species occurrence data}

A list of 217 palm species occurring in the Amazon was extracted from existing publications (Kahn \& Granville 1992; Henderson 1995; Henderson et al. 1995; Kahn 2008; Pintaud et al. 2008; Balslev et al. 2015). After updating and making the nomenclature uniform using the TROPICOS website (http: //www.tropicos.org/) we ended up with a final list of 177 palm species occurring in the Amazon region. For these 177 palm species we obtained 309,277 occurrence records from the Global Biodiversity Information Facility online website (GBIF - http: //www.gbif.org). After doing the cleaning, and taking out duplicate and doubtful data, our final dataset included 17,310 occurrence records of which 11,462 records were georeferenced. For the remaining 5,848 records ( $34 \%$ ) we were able to find coordinates using TROPICOS (http: //www.tropicos.org/) and digital maps, such as Google Earth (http: //earth.google.com/intl/pt/). (Fig. 1A) (Tab. S1 in supplementary material).

\section{Data analyzes}

Palm species distribution records in the Amazon region were plotted on a map divided into 494 grid squares of $1 \times 1^{\circ}$ representing our Operating Geographic Units (OGU). This was done to facilitate the manipulation of data, and partly to reduce the effects of sampling artifacts, such as mapping errors and grid squares positioning in sparsely populated areas (roadmap effect). All procedures used DIVA-GIS 7.5 (http: //www.diva-gis.org/). For each grid square, the species richness was calculated as the total number of palm species present. This analysis was conducted for the entire Amazon basin and also separately for each sub-region. Additionally, at each latitudinal band (range of $1^{\circ}$ ) we also calculated the total number of palm species.

To evaluate if there was a correlation between the number of records and the observed richness (the sample effort), a Pearson correlation coefficient analyzes was performed using DIVA-GIS 7.5. This analyzes was also conducted for the entire Amazon basin and for each sub-region.

Species richness were overlaid with deforestation shapefiles for the period 2001-2012 taken from WWF's deforestation report (2014), to infer whether the areas with lowest species richness and records gaps were due to suppression of forest vegetation or if they represent lack of research in these areas. The report (WWF 2014) use forest data generated by Global Forest Change 2013 (Hansen et al. 2013) supported by the University of Maryland, additional complementary data from PRODES of the Instituto Nacional de Pesquisas Espaciais (INPE) for Brazil, and literature reviews. Our data therefore, described the change in the dynamics of deforestation across the Amazon region, showed a significant decline in the rate of deforestation in the Brazilian Amazon but increasing rates of deforestation in the Andean Amazon countries (WWF 2014).

To determine the similarity between sub-regions, we analyzed Jaccard distance (Gotelli \& Ellison 2011) in the R program version 3.3.1, that measures the similarity between two sets. This analyzes were done with presence/absence data. The Jaccard distance is derived as $1-S$ (the Jaccard's similarity coefficient between two samples). The formula for this analyzes is: $D_{j}=b+c /(a+b+c)$, where: $D_{j}=$ The Jaccard distance between samples 1 and 2; $a=$ number of species common to samples 1 and $2 ; b=$ number of species only found in sample 1 , and $c=$ number of species only found in sample 2 . The result of this analysis was plotted in a dendrogram constructed using the UPGMA binding method (cluster analysis) (Magurran 2011).

\section{Results}

The 177 palm species represented in 17,310 records, were distributed in all regions of the Amazon (Fig. 1A). The sub-region with the largest palm species richness was the Amazonia sensu stricto (167 species). The other sub-regions had substantially lower numbers of species: Guianas (91), and Andes (71). The sub-regions with fewest palm species were the Gurupi (21 species) and the Plateau (17). Twentysix species were endemic to different countries, 14 to Peru, five to Bolivia, three to Colombia, two to Ecuador and two species were endemic to Guiana. The 10 species with the highest number of records were Geonoma macrostachys (1206), Euterpe precatoria (859), Iriartella setigera (617), 
Lepidocaryum tenue (590), Chamaedorea pauciflora (577), Desmoncus mitis (549), Astrocaryum aculeatum (457), Bactris hirta (423), Geonoma brongniartii (400), and Oenocarpus bacaba (391) (Tab. S1 in supplementary material).

The greatest richness (29-71 species) were found in the western (Brazil, Colombia, Ecuador and Peru), central (Manaus) and northeastern (French Guiana) parts of the Amazon (Fig. 1B). Notably, the species richness was lower (1-14 species) on the outskirts of the Amazon region, especially in the eastern, southern and south-eastern Amazon (Fig. 1B). In relation to the latitudinal gradient, high species richness were found between $0-5^{\circ} \mathrm{S}$ (Fig. 1B), with most species (119) in the latitudes $2-3^{\circ} \mathrm{S}$, followed by latitudes $4-5^{\circ} \mathrm{S}(116)$ and $3-4^{\circ} \mathrm{S}(109)$. All of them are under the equatorial line (Fig. 1B).

The Amazon sensu stricto sub-region (Fig. 2A) showed highest richness (44-71 species) in the Peruvian Amazon, around the city of Iquitos (Peru), followed by grid squares with 15-57 species in the central Amazon (around Manaus, Brazil). Furthermore, 29-43 species were distributed in different parts of the western Amazon. The Andean subregion (Fig. 2B) showed grid squares with highest richness (26 species) in two areas; in Pasco Departament, Peru (central Andes) and along border between Peru and Ecuador (northern Andes). In general, the greatest richness were found in northern (Colombia and Ecuador) and central (Peru) parts of the Andes sub-region, decreasing to the south (five species in Bolívia). The Guiana sub-region (Fig. 2C) showed greatest richness in the eastern parts of the subregion. Specifically, the highet richness was found in French Guiana with 35 species. Other areas with high richness (1528 species) were on the border of Colombia and Venezuela, and with 14 species near the Andes sub-region (western Guiana sub-region). The Gurupi sub-region (Fig. 2D) is a small area in eastern Brazil that showed high richness (10 species) along the border between the states of Pará and Maranhão and 5-8 species in the state of Maranhão. Finally, the Plateau sub-region (Fig. 2E) was the area where we found the lowest palm richness (up to five species) among all the sub-region.

The observed species richness and the number of database records per grid square were highly correlated (Pearson correlation, $\mathrm{R}^{2}=0.76, \mathrm{P}<0.005$ ), showing that sampling effort strongly affects the observed species richness in each grid cell. In addition, in each sub-region we also performed this analysis resulting in high correlation, Amazon sensu stricto $\left(R^{2}=0.77\right)$, Andes sub-region $\left(R^{2}=\right.$ $0.71)$, Guiana $\left(R^{2}=0.81\right)$, Gurupi $\left(R^{2}=0.66\right)$ and Plateau $\left(\mathrm{R}^{2}=0.79\right)$.

Low species richness (1-14 species) and gaps in the records were found throughout the entire Amazon region, especially in Amazonia sensu stricto (Fig. 3). Highest rates of deforestation $\left(\geq 2000 \mathrm{~km}^{2}\right)$ were found in southern and eastern Brazilian Amazon. Therefore, in this area the low richness and records gaps with the deforestation must be related. However, areas with higher richness (> 29 species) (western Amazon) also had deforested areas but they were $\leq 500 \mathrm{~km}^{2}$ in extension.

Cluster analyzes using Jaccard distance (Fig. 4) showed two groups with similarity between them, with cophenetic correlation 0.843 . The first group was composed of the three sub-regions (Amazon sensu stricto, Andes and Guiana), and the other group of Gurupi and Plateau sub-region.

\section{Discussion}

\section{How is palm species richness distributed in the Amazon region?}

Palm diversity is notoriously high and palms are widely distributed in Neotropical forests (Cintra et al. 2005; Montufar \& Pintaud 2006) (Fig. 1A). This distribution pattern coincides with global patterns for angiosperms (Barthlott et al. 1996; 2005; 2007; Francis \& Currie 2003; Steege et al. 2006). Both individual palm species' distributions and patterns of palm species richness are related to current climate (Eiserhardt et al. 2011b). Global centres of vascular plants diversity coincide with highly structured, geodiverse areas in the tropics and subtropics such as the tropical eastern Andes, north-western Amazonia and eastern Brazil (Mutke \& Barthlott 2005).

Of the 177 palm species (Tab. S1 in supplementary material), those with high number of records are small palms (e.g., Geonoma macrostachys, Lepidocaryum tenue, Chamaedorea pauciflora, Desmoncus mitis) therefore they are easier to sample. This may be an explanation of the discrepancy in the number of records compared to species of larger size.

We found that palm species had the greatest richness in the western Amazon principally in the Colombian, Ecuadorian and Peruvian Amazon, in central Amazon (around Manaus) and north-eastern Amazon (French Guiana) (Fig. 1B). Several other studies of plants have demonstrated similar patterns, with high species richness and diversity, principally at local scales (e.g., Kahn et al. 1988; Oliveira \& Mori 1999; Cintra et al. 2005; Macía \& Svenning 2005) and continental scales (e.g., Barthlott et al. 1996; 2005; 2007; Bjorholm et al. 2005; Eiserhardt et al. 2011a; b) across the Americas. Salm et al. (2007) found the highest number of species in regions with high humidity (vapor pressure) and low seasonality in the Brazilian Amazon. Thus, not only water-related variables might be strong determinants of palm richness, but also temperature seasonality or extremes (Eiserhardt et al. 2011b) and species richness changes may be explained also by the availability of water and energy within megathermal climates, at least for strictly tropical taxa such as palms (Eiserhardt et al. 2011a).

In the Amazon sensu stricto (Fig. 2A), the western region is well known for its high diversity of plants (Gentry 1988; Duivenvoorden \& Lips 1995; Pitman et al. 2002; Valencia et 

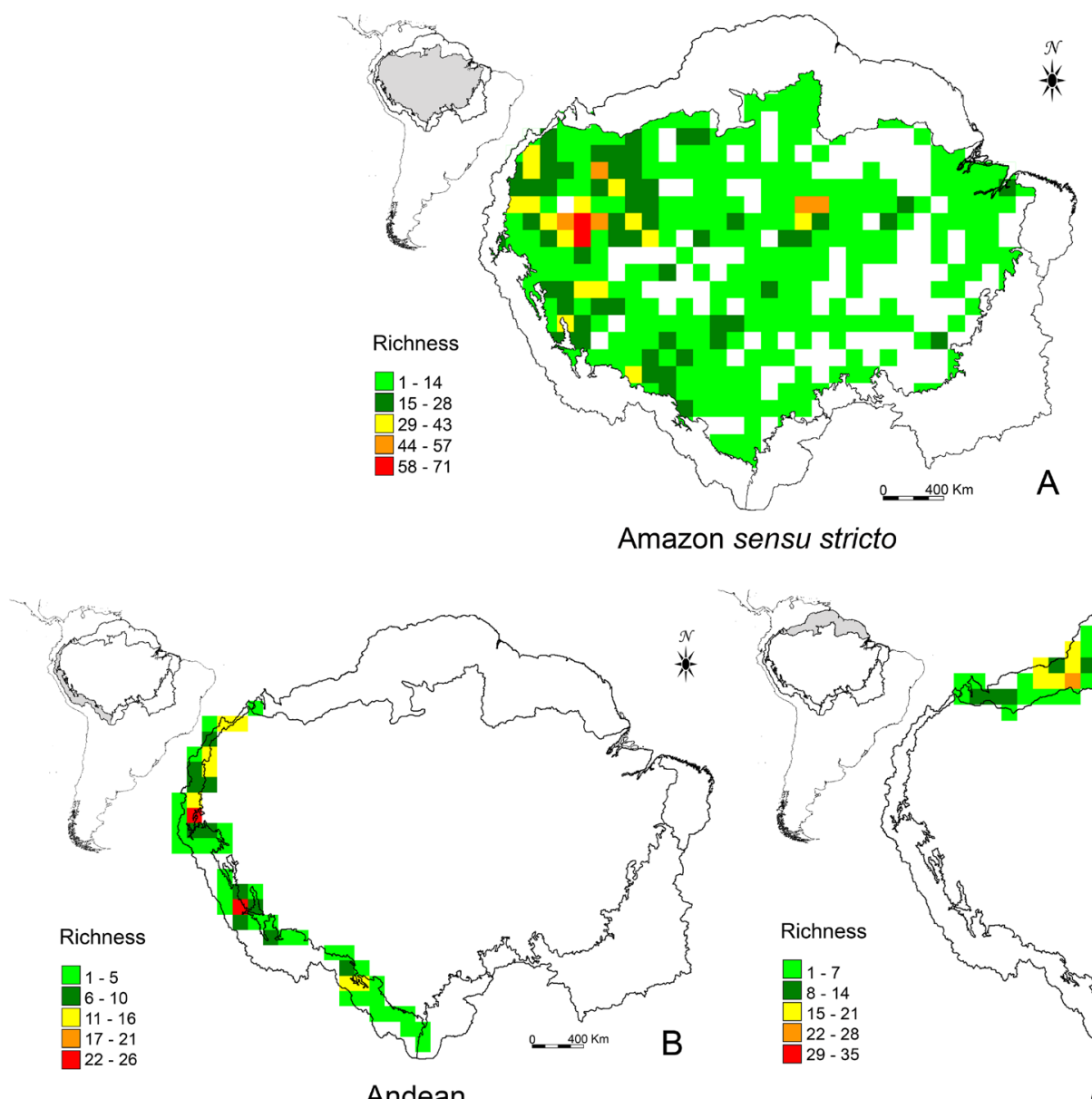

Andean

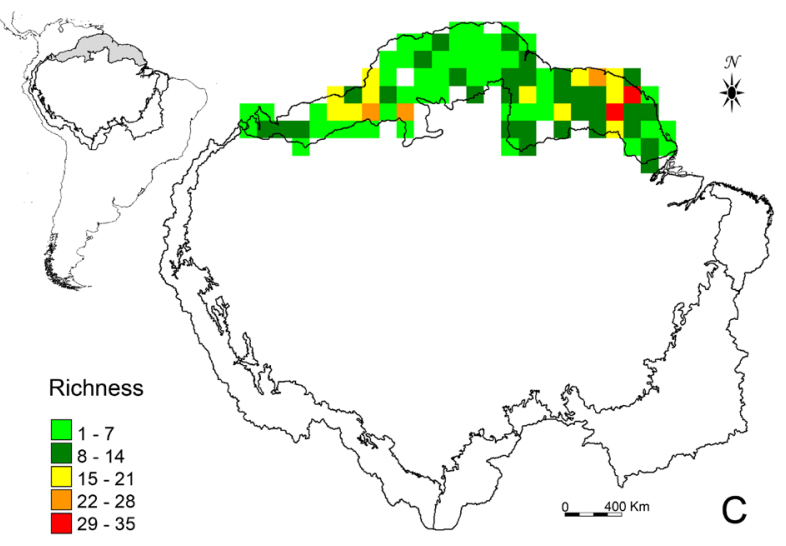

Guiana
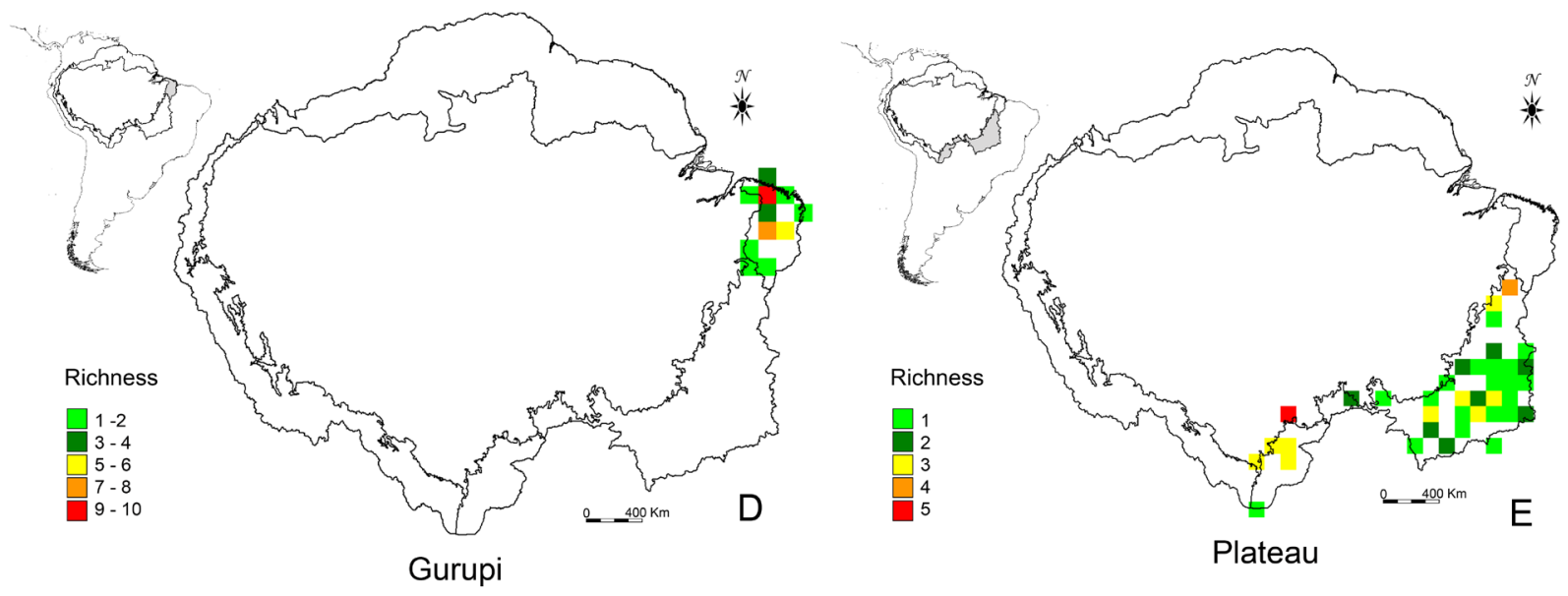

Plateau

Figure 2. Species richness of palms in the five sub-regions of Amazon region. A. Amazon sensu stricto; B. Andean; C. Guiana; D. Gurupi; E. Plateau. Grid squares: $1^{\circ} \times 1^{\circ}$. Please see the PDF version for color reference.

al. 2004) and that region presents one of the richest palm floras in the Neotropical region, with at least 121 species and 33 genera (Montufar \& Pintaud 2006), as well as high endemism rates (Alvez-Valles et al. 2018). The north-western Amazon has a more recent relationship with Central America and the western Andes of Peru, Ecuador and Colombia (Amorin 2001). Several researchers have found high palm richness in different locations in the western Amazon, mainly in the Iquitos-Pebas region in Peru (Kahn \& Mejia 1991; Vormisto 2002; Vormisto et al. 2004a; b), the Yasuní National Park, Ecuador (Svenning 1999), and in the middle basin of Caquetá, Araracuara, Colombia (Galeano 1992; Balslev et al. 2017). The diversity in these areas is high due to species shared with the Andes and its altitudinal gradient (Pintaud et al. 2008). In addition, several studies have shown that the difference in local and regional diversity 


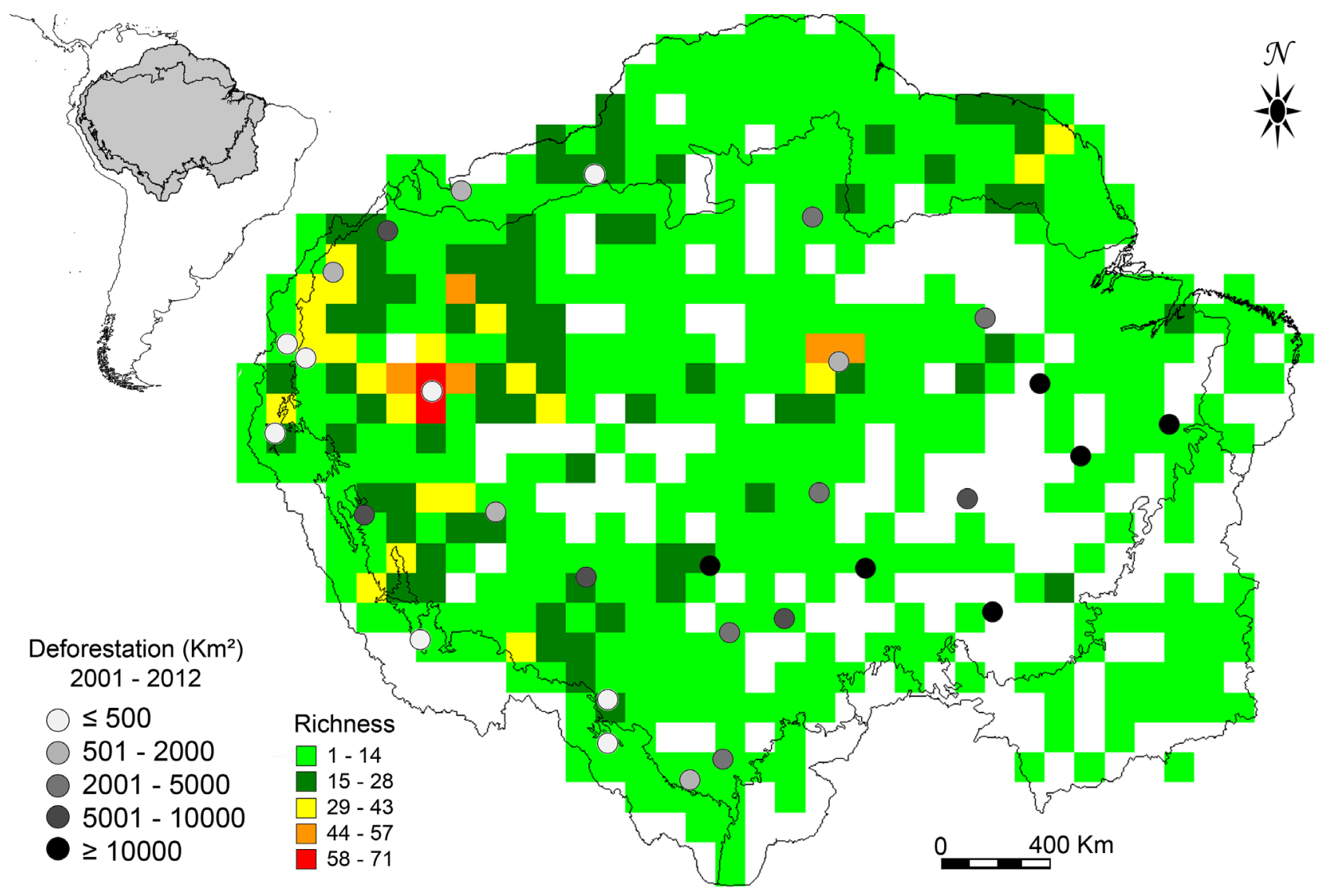

Figure 3. Comparison between the richness of Amazonian palms species and deforestation areas (circles) between the years 2001 and 2012. Please see the PDF version for color reference.

between the Iquitos-Pebas region (Peru) and the Yasuní region (Ecuador) can been attributed to soil fertility and soil types (Montufar \& Pintaud 2006; Vormisto et al. 2004a; Eiserhardt et al. 2011b). Interestingly, the Iquitos-Pebas region supports more species (71 species in this study), although this region has poorer soils but presents a greater variety of soil types (Vormisto et al. 2004b). Another area with high richness (15-57 species) is the central Amazon near Manaus, where the floristic composition may be related to local and regional geological features, with a dry corridor barrier to the north, and possibly with Pleistocene refuges (Prance 1973). A particular phenomenon is the riverine flora of black waters and white sand. Therefore, these areas present two features: high biodiversity in extremely poor soils and large number of restricted species, principally the endemic genera Barcella and Leopoldinia (Oliveira et al. 2001; Pintaud et al. 2008).

The Andean sub-region presents a broad range of landscapes and climatic conditions (Lozano et al. 2009) that result in a megadiverse flora in the equatorial sector (Romero-Saltos et al. 2001; Duque et al. 2001). In this sub-region (Fig. 2B), we found high species richness (1126 species) in the north (Peru, Ecuador and Colombia), center (Peru) and south (northern Bolivia). This pattern

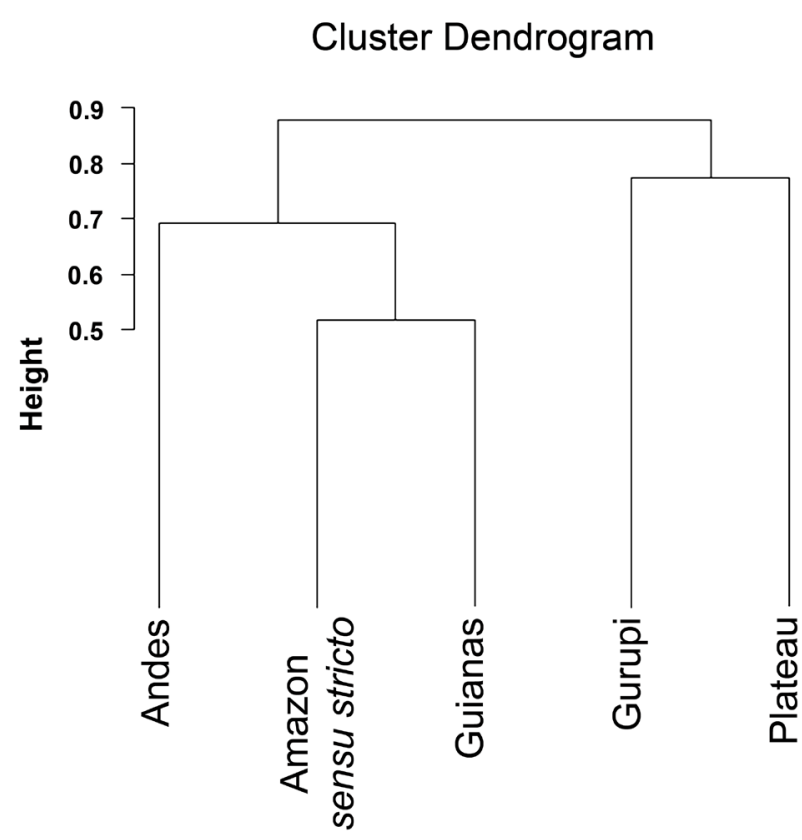

Figure 4. Dendrogram (Jaccard's similarity coefficient) obtained in the similarity analyzes with the five Amazon sub-regions based on a binary matrix of 177 Amazonian palm species. Ass - Amazon sensu stricto; An - Andes; Gui - Guiana; Gur - Gurupi; Pla - Plateau. 
of high diversity, especially in the north, is related to greater topographic complexity and prevalence of humid environments (Pintaud et al. 2008). Therefore, palm richness decreases to the extremes of the sub-region (Borchsenius \& Moraes 2006). In the northern parts of the Andes sub-region we found areas with high species richness especially along the border between Peru and Ecuador (26 species). In this area, the climate is very humid and regional isolation act as a natural barrier and is considered keys in the geographical distribution of plants (Lozano et al. 2009). Several palms studies made in the Ecuadorian Andean forest show that the southern regions of Ecuador may be the richest in species (Balslev et al. 2015). In central Peru in the Pasco department we also found high richness with 26 species. This area is important because it includes three protected natural areas (PNA): Yanachaga-Chemillén Natural Park, San Matias San Carlos Protection Forest, and Yanesha Community Reserve. Consequently, there is at present a good state of conservation of the forests. The diversity in this area is very heterogeneous (Vega et al. 2008), with high endemism (Kahn \& Moussa 1994; León et al. 2006; Young 2007; 2009; Damián 2013) and palms were among the 15 most species rich families in the area (Vásquez et al. 2005).

The Guiana sub-region (Fig. 2C) is biogeographically unique with diverse and abundant vegetation, and many endemic species (Maguire 1970; Gibbs \& Barron 1993; Kelloff \& Funk 2004), principally in its eastern parts (Guiana, Suriname, and French Guiana - Guiana shield). We found high species richness (35) in French Guiana. In comparison with the western Amazon, the eastern Amazon - principally the Guiana shield - presents lower diversity in both mammals (Voss \& Emmons 1996; Kay et al. 1997) and plants (Steege 1998), including palms (Kahn \& Granville 1992). The reduced diversity is not due to low rainfall or low nutritional status of the soil, but to the reduced extension of the area (Steege et al. 2000). Another area with high richness (15-28 species) is along the border between Colombia and Venezuela (the western part of this sub-region). Despite their high species richness and endemism, and presence of PNA such as Yapacana National Park and Sipapo forest reserve (Venezuela), these areas experience strong external pressure from mining and environmental degradation, and indirectly by mercury pollution and increased sediment load in rivers (Lasso et al. 2006; Castillo \& Salas 2007).

Two remaining areas of the Amazon region (Gurupi and Plateau sub-regions) have low species richness (Fig. 2D-E), but stand out for their floristic composition (Pintaud et al. 2008). This low richness may be because this part of the Amazon has savannas with physiognomic similarity and affinities to the floristic composition of the cerrado (Brazilian savanna). Therefore, it is an area of transition between the Amazon rainforest and drier formations of southern and south-eastern Brazil (Pintaud et al. 2008). In the same way, the eastern Amazon (Gurupi sub-region) (Fig. 2D) has low palm richness and lacks endemism due to its environmental homogeneity, sedimentation, and floodplains around the mouth of the Amazon River (Pintaud et al. 2008; AlvezValles et al. 2018). Besides, the south-eastern Amazon (plateau sub-region) (Fig. 2E) has more recent relations with the Atlantic Forest than with the north-western Amazon (Amorin 2001).

The relationship between species richness and latitude in palms is driven mainly by a gradient in net diversification rates that have been operative throughout the evolutionary history of New World palms (Svenning et al. 2008). Notably, this hypothesis proposes that more species-rich areas have experienced higher rates of net diversification due to higher speciation rates and/or lower extinction rates (Mittelbach et al. 2007; Svenning et al. 2008). The most species-rich grid square was found near the equator at latitudes $0-5^{\circ} \mathrm{S}$ (Fig. 1B) which coincides with the results of Bjorholm et al. (2005). Thus, the biogeographic patterns in the Amazon region involve a correlation of palm diversity with a gradient of rainfall from the central parts of the region to its periphery (Pintaud et al. 2008). Climatic influences vary strongly with latitude, principally in plants (Francis \& Currie 2003). Thus, plant diversity generally present peaks where climatic conditions are warm, wet and more seasonally stable (Eiserhardt et al. 2011b). Therefore, the global distribution of the palms is concentrated in warm and humid climates (Eiserhardt et al. 2011b) with mean annual precipitation $\geq 2400 \mathrm{~mm}, \geq 160$ wet days per year, and mean annual temperatures $\geq 21^{\circ} \mathrm{C}$. From such regions species richness declines strongly with latitude, as conditions become colder and drier, with more seasonally variable temperature (Francis \& Currie 2003; Bjorholm et al. 2005). This decline is observed in our results, while latitude increases (north and south), the species richness declines (Fig. 1B).

\section{Is the observed palm species richness related to sample effort?}

According to our results of the Pearson correlation coefficient analysis $\left(R^{2}=0.76\right)$, the observed species richness is influenced by the sampling effort. Similar results were found in all five sub-regions. Therefore, areas with high species richness are those with highest number of records. However, there is strong evidence of sampling bias in this result, sometimes called "the museum effect" (Ponder et al. 2001), which implies that for historical reasons of efficiency, logistics and convenience, collectors tend to oversample near research institutions (Werneck et al. 2011) resulting in a greater number of species in those areas. For example, the greatest palms richness corresponded to areas of high overall plant diversity (Peruvian and Ecuadorian Amazon, and around Manaus) as recognized previously by several floristic inventories (Kahn \& Castro 1985; Gentry 1988; Kahn et al. 1988; Kahn \& Mejía 1990; 1991; Pitman et al. 2001; 2002; Haugaasen \& Peres 2006; Honorio et al. 
2008; Pintaud et al. 2008; Vedel-Sørensen et al. 2013). There are important research efforts in these areas, such as those of the Instituto Nacional de Pesquisas da Amazônia (INPA) around Manaus, Brazil, Instituto de Investigación de la Amazonía Peruana (IIAP and Herbarium Amazonense HAMAZ) in Iquitos,Peru, Missouri Botanical Garden in Oxapampa, Peru, and Herbario QCA, Pontificia Universidad Católica del Ecuador, Quito, Ecuador.

\section{Are low richness and record gaps related to} deforestation?

The areas with highest rate of deforestation ( $\geq 2000$ $\mathrm{km}^{2}$ ) are in the southern and south-eastern Amazon sensu stricto, areas which also have low richness and many record gaps (Fig. 3A). The deforestation is a negative factor that puts a high proportion of plants at risk of extinction (Steege et al. 2015), which may also be the reason there are so few collections of palms from there. The deforestation in those areas appears to be particularly severe due to high deforestation rates and ecological sensitivity to climate change (Coe et al. 2013). It is important to note that there deforestation $\left(<2000 \mathrm{~km}^{2}\right)$ also occur in areas with high species richness in the western Amazon and Andean subregion. Therefore, greater emphasis should be given to conservation in these areas, because this activity may in the future lead to reduced richness and even extinction of some palms (Steege et al. 2015). On the other hand, there are areas with low richness and records gaps in nondeforested areas, which can be explained by other factors such a difficult access, and lack of logistics and interest in exploring these areas. The Plateau and Gurupi sub-regions also presented low richness and record gaps. Those areas are located in the ecotone with the cerrado (Brazilian savanna), a phytogeographic domain where the palm diversity is lower in comparison with the Amazon (BFG 2015). Therefore, this result shows that the deforestation is not only responsible for the low richness and records gaps.

\section{Are there floristic similarities in palms distribution patterns among the Amazonian sub-regions?}

According to cluster analyzes of Jaccard distance we found two groups of similarity. One group corresponded to Amazon sensu stricto, the Guiana and Andes sub-regions, and another group was composed by the Gurupi and Planalto sub-regions. Several palm species growing on the eastern slopes of the Andes are also found in the western Amazon (Pintaud et al. 2008) and there are species shared between eastern Amazon and Guiana shield (ter Steege et al. 2000). However, Gurupi and Plateau sub-region although they have low species richness, also present species shared between them, highlighting that several species extend until the cerrado domain and Atlantic Forest (Amorin 2001; Pintaud et al. 2008).
In conclusion, the greatest palm richness was found at latitudes near the equatorial belt $\left(0-5^{\circ} \mathrm{S}\right)$, principally in the western Amazon (Andes sub-region and Amazon sensu stricto) and east of the Guiana sub-region. In contrast, low richness was found in the Plateau and Gurupi subregions. According to Pearson correlation coefficient in each sub-region, the species richness was highly related to the sampling effort. The low richness and records gaps may have been caused by deforestation principally in southern and south-eastern Brazilian Amazonia, but in other areas with records gaps it may probably have been caused by difficult access and lack of logistics and research. Furthermore, the low richness must also be due to the existence of ecological transitional areas where palm species are known to have poor representation (Plateau and Gurupi sub-region). The pattern of species distribution played an important role for understanding the similarity between the subregions. Finally, we recommend giving greater focus of palm research in areas with few records of occurrence especially in areas with records gaps, for a better knowledge of their diversity and richness patterns. Therefore, the installation of research institutions and/or researches in areas of low sampling would increase the number of records, increasing the knowledge of the local flora.

\section{Acknowledgements}

The authors thank the Universidade Federal de Juiz de Fora (UFJF), CAPES (Coordenação de Aperfeiçoamento de Pessoal de Nível Superior), OEA (Organización de estados Americanos) and GCUB (Grupo Coimbra de Universidades Brasileiras) for financial support. HB thanks the Danish Council for Independent Research - Natural Sciences [grant\#4181-00158] and the European Community [FP7 grant \#212631]. The authors also thank the reviewers for contributing with their comments.

\section{References}

Alvez-Valles CM, Balslev H, Carvalho FA, Garcia-Villacorta R, Grandez C, Menini Neto L. 2018. Endemism and conservation of Amazon palms. Biodiversity and Conservation 27: 765-784.

Amorin DS. 2001. Dos Amazonías. In: Llorente-Bousquets J, Morrone J. (eds.) Introducción a la biogeografía en Latinoamérica: Teorías, conceptos, métodos y aplicaciones. Ciudad de México, UNAM. p. 245-256.

Balslev H, Copete J-C, Pedersen D, et al. 2017. Palm diversity and abundance in the Colombian Amazon. In: Myster RW. (ed.). Forest structure, function and dynamics in Western Amazonia. London, John Wiley \& Sons Ltd. p. 101-123.

Balslev H, Kahn F, Millan B, et al. 2011. Species diversity and growth forms in Tropical American palm communities. The Botanical Review 77: 381-425

Balslev H, Pedersen D, Navarrete H, Pintaud J. 2015. Diversidad y abundancia de palmas. In: Balslev H, Macía M, Navarrete H. (eds.) Cosecha de palmas en el noroeste de Suramérica: bases científicas para su manejo y conservación. Quito, Pontificia Universidad Católica del Ecuador. p. 13-25. 
Balslev H, Valencia R, Mino GP, Christensen H, Nielsen I. 1998. Species count of vascular plants in one hectare of humid lowland forest in Amazonian Ecuador. In: Dallmeier F, Comiskey JA. (eds.) Forest biodiversity in North, Central, and South America, and the Caribbean: research and monitoring. Paris/Carnforth, UNESCO/The Parthenon Publishing Group. p. 585-594.

Barot S, Mitja D, Miranda I, Meija Gd, Grimaldi M. 2005. Reproductive plasticity in an Amazonian palm. Evolutionary Ecology Research 7: 1-15.

Barthlott W, Hostert A, Kier G, et al. 2007. Geographic patterns of vascular plant diversity at continental to global scales. Erdkunde 61: 305-316.

Barthlott W, Lauer W, Placke A. 1996. Global distribution of species diversity in vascular plants: towards a world map of phytodiversity. Erdkunde 50: 317-328.

Barthlott W, Mutke J, Rafiqpoor MD, Kier G, Kreft H. 2005. Global centres of vascular plant diversity. Nova Acta Leopoldina 92: 61-83.

BFG -The Brazil Flora Group. 2015. Growing knowledge: an overview of Seed Plant diversity in Brazil. Rodriguésia 66: 1085-1113.

Bjorholm S, Svenning JC, Baker WJ, Skov F, Balslev H. 2006. Historical legacies in the geographical diversity patterns of New World palm (Arecaceae) subfamilies. Botanical Journal of the Linnean Society 151: 113-125.

Bjorholm S, Svenning JC, Skov F, Balslev H. 2005. Environmental and spatial controls of palm (Arecaceae) species richness across the Americas. Global Ecology \& Biogeography 14: 423-429.

Blach-Overgaard A, Svenning JC, Dransfield J, Greve M, Balslev H. 2010. Determinants of palm species distributions across Africa: the relative roles of climate, non-climatic environmental factors, and spatial constraints. Ecography 33: 380-391.

Borchsenius F, Moraes MR. 2006. Diversidad y usos de palmeras andinas (Arecaceae). In: Moraes MR, Øllgaard B, Kvist LP, Borchsenius F, Balslev H. (eds.) Botánica Económica de los Andes Centrales. La Paz, Herbario Nacional de Bolivia, Universidad Mayor de San Andrés, Plural Editores La Paz. p. 412-433.

Brown KS, Ab'saber AN. 1979. Ice-age forest refuges and evolution in the neotropics: correlation of paleoclimatological, geomorphological and pedological data with modern biological endemism. Paleoclimas 5: 1-30.

Canhos DA, Sousa-Baena MS, Souza S, et al. 2015. The importance of biodiversity e-infrastructures for megadiverse countries. PLoS Biology 13(7): e1002204. doi: 10.1371/journal.pbio.1002204

Castillo R, Salas V. 2007. Estado de Conservación del Parque Nacional Yapacana. Reporte especial. http://www.portalces.org/sites/default/ files/reportepnyapacana2007.pdf. 05 Mar. 2017.

Cintra R, Ximenes A, Gondim F, Kropf M. 2005. Forest spatial heterogeneity and palm richness, abundance and community composition in Terra Firme forest, Central Amazon. Revista Brasileira de Botânica 28: 75-84

Coe MT, Marthews TR, Costa MH, et al. 2013. Deforestation and climate feedbacks threaten the ecological integrity of south-southeastern Amazonia. Philosophical Transactions of the Royal Society B 368: 20120155. doi: 10.1098/rstb.2012.0155

Connell JH, Orias E. 1964. The ecological regulation of species diversity. American Naturalist 98: 399-414.

Damián A. 2013. Diversidad y distribución altitudinal de especies terrestres de la familia Orchidaceae en un bosque montano al interior del Parque Nacional Yanachaga Chemillen (Pasco, Perú). Arnaldoa 20: 103-116.

Dobzhansky T. 1950. Evolution in the tropics. American Scientist 38: 209-221.

Duivenvoorden JF, Lips JM. 1995. A land-ecological study of soils, vegetation, and plant diversity in Colombian Amazonia. Tropenbos Series 12. Wageningen, Tropenbos Foundation.

Duque A, Sánchez M, Cavelier J, Duivenvoorden JF, Matapi A. 2001. Relación bosque-ambiente en el Medio Caquetá, Amazonía colombiana. In: Duivenvoorden JF, Balslev H, Cavelier J, Grandez C, Tuomisto H, Valencia R. (eds.) Evaluación de recursos vegetales no maderables en la Amazonía noroccidental. Amsterdam, IBED Universiteit van Amsterdam. p. 99-129.

Eiserhardt WL, Bjorholm S, Svenning J-C, Rangel TF, Balslev H. 2011a. Testing the water-energy theory on American palms (Arecaceae) using
Geographically Weighted Regression. PLoS ONE 6(11): e27027. doi: 10.1371/journal.pone.0027027

Eiserhardt WL, Svenning J-C, Kissling WD, Balslev H. 2011b. Geographical ecology of the palms (Arecaceae): Determinants of diversity and distributions across spatial scales. Annals of Botany 108: 1391-1416.

Eva HD, Huber O. (eds.) 2005. A proposal for defining the geographical boundaries of Amazônia. In: Expert Consultation Workshop. Ispra, European Commission in collaboration with the Amazon Cooperation Treaty Organization - JRC.

Fearnside, PM. 1992. Desmatamento e desenvolvimento agrícola na Amazônia brasileira. In: Léna P, Oliveira AE. (org.) Amazônia: a fronteira agrícola 20 anos depois. Belém, Cejup: Museu Paraense Emílio Goeldi. p. 207.

Feeley KJ, Silman MR. 2011. The data void in modeling current and future distributions of tropical species. Global Change Biology 17: 626-630.

Fischer AG. 1960. Latitudinal variation in organic diversity. Evolution 14: 64-81.

Francis AP, Currie DJ. 2003. A globally consistent richness-climate relationship for angiosperms. The American Naturalist 161: 523-536.

Franklin J. 2009. Mapping species distributions: spatial inference and prediction. Cambridge, Cambridge University Press.

Galeano G. 1992. Las Palmas de la Región de Araracuara. Santa Fé de Bogotá, Tercer Mundo Editores.

Gaston KJ. 2009. Geographic range limits of species. Proceedings of the Royal Society of London B 276: 1391-1393.

Gentry AH. 1988. Tree species richness of upper Amazonian forests. Proceedings of the National Academy of Sciences of the United States of America 85: 156-159.

Gentry AH. 1991. Four neotropical rainforests. London, Yale University Press.

Gibbs AK, Barron CN. 1993. The geology of the Guyana Shield. Oxford, Clarendon Press.

Gotelli NJ, Ellison AM. 2011. Princípios de estatística em ecologia. Porto Alegre, Artmed.

Graham CH, Ferrier S, Huettman F, Moritz C, Peterson AT. 2004. New developments in museum-based informatics and applications in biodiversity analysis. Trends in Ecology \& Evolution 19: 497-503.

Haffer J. 1969. Speciation in Amazonian forest birds. Science 165: 131-137.

Hansen MC, Potapov PV, Moore R, et al. 2013. High-resolution global maps of 21st-century forest cover change. Science 342: 850-853.

Haugaasen T, Peres SCA. 2006. Floristic, edaphic and structural characteristics of flooded and unflooded forests in the lower Rio Purús region of central Amazonia, Brazil. Acta Amazonica 36: 25-36.

Henderson A. 1995. The Palms of the Amazon. New York, Oxford University Press.

Henderson A, Galeano G, Bernal R. 1995. Field guide to the palms of the Americas. Princeton, Princeton University Press.

Heijden GMF, Phillips OL. 2009. Environmental effects on Neotropical liana species richness. Journal of Biogeography 36: 1561-1572.

Hillebrand H. 2004. On the generality of the latitudinal diversity gradient. The American Naturalist 163: 192-211.

Holdsworth AR, Uhl C. 1997. Fire in Amazonian selectively logged rain forest and the potential for fire reduction. Ecological Applications 7: 713-725.

Honorio E, Pennington RT, Freitas L, Nebel G, Baker T. 2008. Análisis de la composición florística de los bosques de Jenaro Herrera, Loreto, Perú. Revista Peruana de Biología 15: 53-60.

Johns J, Barreto P, Uhl C. 1996. Logging damage in planned and unplanned logging operation and its implications for sustainable timber production in the eastern Amazon. Forest Ecology and Management 89: 59-77.

Kahn F. 2008. The genus Astrocaryum (Arecaceae). In: Millán B, Kahn F, Arana C. (eds.) Las Palmeras en America del Sur. Revista Peruana de Biología 15: 31-48.

Kahn F, Castro A. 1985. The palm community in a forest of Central Amazonia, Brazil. Biotropica 17: 210-216.

Kahn F, Granville JJ. 1992. Palms in forest ecosystems of Amazonia. Ecological studies. Vol 95 - Analysis and synthesis. New York, Ed. Oldeman R A. Springer-Verlag. 
Kahn F, Mejia K. 1990. Palm communities in wetland forest ecosystems of Peruvian Amazonia. Forest Ecology and Management 33: 169-179.

Kahn F, Mejia K. 1991. The palm communities of two terra firme forests in Peruvian Amazonia. Principes 35: 22-26.

Kahn F, Mejia K, Castro A. 1988. Species richness and density of palms in Terra Firme forests of Amazonia. Biotropica 20: 266-269.

Kahn F, Moussa F. 1994. Las Palmeras del Perú - Colecciones, Patrones de distribución geográfica, ecología, estatutos de conservación, nombres vernáculos, utilizaciones. Lima, Instituto Francés de Estudios Andinos - IFEA.

Kay RF, Madden RH, Schaik C, Higdon D. 1997. Primate species richness is determined by plant productivity: implications for conservation. Proceedings of the National Academy of Sciences United States of America 94: 13023-13027.

Kelloff C, Funk V. 2004. Phytogeography of the Kaieteur Falls, Potaro plateau, Guyana: Floral distributions and affinities. Journal of Biogeography 31: 501-513.

Klopfer PH. 1959. Environmental determinats of faunal diversity. American Naturalist 93: 337-342.

Lande R, DeVries PJ, Walla T. 2000. When species accumulation curves intersect: implications for ranking diversity using small samples. Oikos 89: 601-605.

Lasso CA, Señarìs JC, Alonso LE, Flores A. (eds.) 2006. Evaluación rápida de la biodiversidad de los ecosistemas acuáticos en la confluencia de los ríos Orinoco y Ventuari, estado Amazonas (Venezuela). Boletín RAP de Evaluación Biológica 30. Washington, Conservation International.

Laurance WF, Albermaz AKM, Fearnside PM, Vasconcelos HLE, Ferreira LV. 2004. Desforestation in amazonia. Science 304: 1109.

León B, Pitman N, Roque J. 2006. Introducción a las Plantas endémicas del Perú. Revista Peruana de Biología. 13: 9S-22S.

Lozano P, Cleef AM, Bussmann RW. 2009. Phytogeography of the vascular páramo flora of Podocarpus National Park, south Ecuador Fitogeografía. Arnaldoa 16: 69-85.

MacArthur RH, MacArthur JW. 1961. On bird species diversity. American Naturalist 42: 594-598.

Macía MJ, Svenning JC. 2005. Oligarchic dominance in western Amazonian plant communities. Journal of Tropical Ecology 21: 613-626.

Maguire B. 1970. On the flora of the Guayana Highland. Biotropica 2: 85-100.

Magurran AE. 2011. Medindo a diversidade biológica. Curitiba, Ed. da UFPR.

Melo AS, Hepp LU. 2008. Ferramentas estatísticas para análises de dados provenientes de biomonitoramento. Oecologia Brasiliensis 12: 463486.

Menini Neto L, Furtado SG, Zappi DC, Oliveira-Filho AT, Forzza RC. 2016. Biogeography of epiphytic Angiosperms in the Brazilian Atlantic forest, a world biodiversity hotspot. Brazilian Journal of Botany 39: 261-273.

Miller AH. 1958. Ecologic factors that accelerate formation of races and species in terrestrial vertebrates. Evolution 10: 262-277.

Mittelbach GG, Schemske DW, Cornell HV, et al. 2007. Evolution and the latitudinal diversity gradient: speciation, extinction and biogeography. Ecology Letters 10: 315-331.

Montufar R, Pintaud JC. 2006. Variation in species composition, abundance and microhabitat preferences among western Amazonian terra firme palm communities. Botanical Journal of the Linnean Society 151: 127-140.

Mutke J, Barthlott W. 2005. Patterns of vascular plant diversity at continental to global scales. Biologiske Skrifter 55: 521-531.

Nobre AD. 2014. The future climate of Amazonia. Scientific Assessment Report. São José dos Campos, ARA, CCST-INPE, INPA.

Oliveira AA, Daly DC, Vicentini A, Cohn-Haft M. 2001. Florestas sobre areia: campinaranas e igapós. In: Oliveira AA, Daly DC. (eds.) Florestas do Rio Negro. São Paulo, Companhia das Letras. p. 179-220.

Oliveira AA, Mori SA. 1999. A central Amazonian terra firme forest. I. High tree species richness on poor soils. Biodiversity and Conservation 8: 1219-1244.

Paine RT. 1966. Food web complexity and species diversity. American Naturalist 100: 65-75.
Patiño J, Mateo RG, Zanatta F, et al. 2016. Climate threat on the Macaronesian endemic bryophyte flora. Nauture, Scientific Reports 6: 29156. doi: 10.1038/srep29156

Pearson RG, Dawson TP. 2003. Predicting the impacts of climate change on the distribution of species: Are bioclimate envelope models useful? Global Ecology \& Biogeography 12: 361-371.

Pianka ER. 1966. Latitudinal gradients in species diversity: a review of concepts. American Naturalist 100: 33-46.

Pielou EC. 1975. Ecological diversity. New York, Wiley.

Pielou EC. 1977. Mathematical ecology. New York, Wiley.

Pintaud JC, Galeano G, Balslev H, et al. 2008. Las Palmeras de América del Sur : diversidad, distribución e historia evolutiva. Revista Peruana de Biología 15: 7-29.

Pitman NCA, Terborgh JW, Silman MR, et al. 2001. Dominance and distribution of tree species in upper Amazonian terra firme forests. Ecology 82: 2101-2117

Pitman NCA, Terborgh JW, Silman MR, et al. 2002. A comparison of tree species diversity in two upper Amazonian forests. Ecology 83: 3210-3224

Ponder WF, Carter GA, Flemons P, Chapman RR. 2001. Evaluation of Museum Collection Data for Use in Biodiversity Assessment. Conservation Biology 15: 648-657.

Prance GT. 1973. Phytogeographic support for the theory of Pleistocene forest refuges in the Amazon basin, based on evidence from distribution patterns in Caryocaraceae, Chrysobalanaceae, Dichapetalaceae and Lecythidaceae. Acta Amazonica 3: 5-28.

Romero-Saltos H, Valencia R, Macías MJ. 2001. Patrones de diversidad, distribución y rareza de plantas leñosas en el Parque Nacional Yasuní y la Reserva Étnica Huaorani, Amazonia ecuatoriana. In: Duivenvoorden JF, Balslev H, Cavelier J, Grandez C, Tuomisto H, Valencia R. (eds.). Evaluación de recursos vegetales no maderables en la Amazonía noroccidental. Amsterdam, IBED, Universiteit van Amsterdam. p. 131-162 pp.

Salm R, Jardim MAG, Albernaz ALKM. 2001. Abundance and diversity of palms in the sustainable forest district of BR-163 road, Pará, Brazil. Biota Neotropica 11: 99-105.

Salm R, Salles NVd, Alonso WJ, Schuck-Paim C. 2007. Cross-scale determinants of palm species distribution. Acta Amazonica 37: 17-25.

Schluter D, Ricklefs RE. 1993. Species diversity: an introduction to the problem. In: Ricklefs RE, Schluter D. (eds.) Species diversity in ecological communities: historical and geographical perspectives. Chicago, The University of Chicago Press. p. 1-10.

Sigrist MS, Carvalho CJB. 2008. Detection of areas of endemism on two spatial scales using Parsimony Analysis of Endemicity (PAE): The Neotropical region and the Atlantic forest. Biota Neotropica 8: 33-42.

Skole D, Tucker C. 1993. Tropical deforestation and habitat fragmentation in the Amazon: satellite data from 1978 to 1988. Science 260: 19051910.

Soares BS, Nepstad DC, Curran LM, et al. 2006. Modelling conservation in the Amazon basin. Nature 440: 520-523.

Soares BS, Rajao R, Macedo M, et al. 2014. LAND USE cracking Brazil's forest code. Science 344: 363-364.

Souza Jr. C, Firestonea L, Silva LM, Roberts D. 2003. Mapping forest degradation in the Eastern Amazon from SPOT 4 through spectral mixture models. Remote Sensing of Environment 87: 494-506

Spracklen DV, Garcia-Carreras L. 2015. The impact of Amazonian deforestation on Amazon basin rainfall, Geophysical Research Letters 42: 9546-9552.

Steege H. 1998. The use of forest inventory data for a National Protected Area Strategy in Guyana. Biodiversity and Conservation 7: 1457-1483.

Steege H, Pitman NCA, Killeen TJ, et al. 2015. Estimating the global conservation status of over 15,000 Amazonian tree species. Science Advances 2015(1): e1500936. doi: 10.1126/sciadv.1500936

Steege H, Pitman NCA, Phillips OL, et al. 2006. Continental-scales patterns of canopy tree composition and function across Amazonia. Nature 443: 444-447.

Steege H, Pitman NCA, Sabatier D, et al. 2003. A spatial model of tree alpha-diversity and tree density for the Amazon. Biodiversity and Conservation 12: 2255-2277. 
Steege H, Sabatier D, Castellanos H, et al. 2000. An analysis of the floristic composition and diversity of Amazonian forests including those of the Guiana Shield. Journal of Tropical Ecology 16: 801-828.

Stiling PD. 1996. Ecology: theories and applications. 2nd. edn. Upper Saddle River, Prentice Hall.

Svenning JC. 1999. Microhabitat specialization in a species- rich palm community in Amazonian Ecuador. Journal of Ecology 87: 55-65.

Svenning JC, Borchsenius F, Bjorholm S, Balslev H. 2008. High tropical net diversification drives the New World latitudinal gradient in palm (Arecaceae) species richness. Journal of Biogeography 35: 394-406.

Terborgh J. 1973. On the notion of favourableness in plant ecology. American Naturalist 107: 481-501.

Turner, IM. 1996. Species loss in fragments of Tropical Rain Forest: A review of the evidence. Journal of Applied Ecology 33: 200-209.

Valencia R, Condit R, Romoleroux K, et al. 2004. Tree species diversity and distribution in a forest plot at Yasuní National Park, Amazonian Ecuador. In: Losos EC, Leigh EG. (eds.) Tropical forest diversity and dynamism. Findings from a large-scale plot network. Chicago, The University of Chicago Press. p. 107-118.

Vanzolini PE. 1970. Zoologia sistemática, geografia e a origem das espécies. São Paulo, Universidade de São Paulo, Instituto de Geografia.

Vásquez R, Rojas GR, Monteagudo MA, et al. 2005. Flora Vascular de la selva central del Perú: Una aproximación de la composición florística de tres Áreas Naturales Protegidas. Arnaldoa 12: 112-125.

Vedel-Sørensen M, Tovaranonte J, Bøcher PK, Balslev H, Barfod AS. 2013. Spatial distribution and environmental preferences of 10 economically important forest palms in western South America. Forest Ecology and Management 307: 284-292.

Vega MS, Gallardo ME, Hernani L, et al. 2008. Análisis de la variación de la diversidad de las comunidades de arbustos de sotobosque entre tres localidades al interior del Parque Nacional Yanachaga Chemillen (Pasco-Perú). Ecología Aplicada 7: 29-42.
Veríssimo A, Barreto P, Mattos M, Tarifa R, Uhl C. 1992. Logging impacts and prospects for sustainable forest management in an old Amazon frontier: The case of Paragominas. Forest Ecology and Management 55: 169-199.

Vormisto J. 2002. Palms as rainforest resources: how evenly are they distributed in Peruvian Amazonia? Biodiversity and Conservation 11: 1025-1045.

Vormisto J, Svenning JC, Hall P, Balslev H. 2004a. Diversity and dominance in palm (Arecaceae) communities in terra firme forests in the western Amazon basin. Journal of Ecology 92: 577-588.

Vormisto J, Tuomisto H, Oksanen J. 2004b. Palm distribution patterns in Amazonian rainforests: what is the role of topographic variation? Journal of Vegetation Science 15: 485-494.

Voss RS, Emmons L. 1996. Mammalian diversity in neotropical lowland rain forests: A preliminary assessment. Bulletin of the American Museum of Natural History 230: 1-115.

Werneck MDS, Sobral MEG, Rocha CTV, Landau ECh, Stehmann JR. 2011. Distribution and endemism of Angiosperms in the Atlantic Forest. Natureza \& Conservação 9: 188-193.

Whitmore TC, Sayer J. 1992. Tropical deforestation and species extinction. London, Chapman \& Hall.

WWF - World Wildlife Fund. 2014. Deforestation fronts in the Amazon Region: current situation and future trends. A preliminary summary. Living Amazon Initiative (LAI). http: //d2ouvy59p0dg6k. cloudfront.net/downloads/wwf_liv_amaz_deforest_fronts_prelim summary_2014dec06_web_.pdf. 18 Aug. 2016.

Yesson C, Brewer PW, Sutton T, et al. 2007. How global is the global biodiversity information facility? PLoS ONE 2(11): e1124. doi: 10.1371/journal.pone.0001124

Young BE. (ed.) 2007. Distribución de las especies endémicas en la vertiente oriental de los Andes en Perú y Bolivia. Arlington, NatureServe.

Young BE, Franke I, Hernandez PA, et al. 2009. Using spatial models to predict areas of endemism and gaps in the protection of Andean slope birds. The Auk 126: 554-565. 